\title{
Topical Over-the-Counter Antiaging Agents: An Update and Systematic Review
}

\author{
Imhof, Laurence ; Leuthard, Deborah
}

\begin{abstract}
Over-the-counter antiaging formulations aim to prevent or minimize the signs of aging skin, and to maintain the benefits obtained from different cosmetic procedures. Even though a huge selection of such products is available on the market, evidence and good clinical practice of the data supporting their use are oftentimes lacking. In this systematic review, the authors reviewed scientific data available in the published literature on the most common ingredients used in antiaging cosmetics, with a particular focus on in vivo studies.
\end{abstract}

DOI: https://doi.org/10.1159/000509296

Posted at the Zurich Open Repository and Archive, University of Zurich ZORA URL: https://doi.org/10.5167/uzh-189864

Journal Article

Published Version

Originally published at:

Imhof, Laurence; Leuthard, Deborah (2021). Topical Over-the-Counter Antiaging Agents: An Update and Systematic Review. Dermatology, 237(2):217-229.

DOI: https://doi.org/10.1159/000509296 


\title{
Topical Over-the-Counter Antiaging Agents: An Update and Systematic Review
}

\author{
Laurence Imhof Deborah Leuthard \\ Department of Dermatology, University Hospital Zurich, Zurich, Switzerland
}

\section{Keywords}

Antiaging · Cosmeceutical · Targeted ingredients ·

Rejuvenational capacity

\begin{abstract}
Over-the-counter antiaging formulations aim to prevent or minimize the signs of aging skin, and to maintain the benefits obtained from different cosmetic procedures. Even though a huge selection of such products is available on the market, evidence and good clinical practice of the data supporting their use are oftentimes lacking. In this systematic review, the authors reviewed scientific data available in the published literature on the most common ingredients used in antiaging cosmetics, with a particular focus on in vivo studies.
\end{abstract}

(c) 2020 S. Karger AG, Basel

\section{Introduction}

During the past years, research on cutaneous aging mechanisms has gained considerable importance. This is due to various reasons - on the one hand, understanding aging mechanisms is crucial for the development of new lifestyle and beauty products, on the other hand, the skin is attracting considerable attention as an indicator of the health status of internal organs [1].

Skin aging is a complex biological process, from birth onwards, though the first signs of skin aging are usually noticeable only in the late twenties. It is based on a complex interplay between proinflammatory factors of the environment, lifestyle, and intra-individual genetics. With aging, cell activity decreases at a molecular level; collagen production reduces, and nonfunctional elastic fibers increase $[2,3]$.

At the center of this process are the so-called free oxygen radicals, also known as reactive oxygen species (ROS), which promote the aging process of the skin [1]. ROS damage of cellular structures such as the DNA or lipid membranes, which leads to upregulation of matrix metalloproteinases (especially MMP1 and MMP2) in fibroblasts; hence, increased breakdown and reduced build-up of collagen and elastin [4].

While very little is known about the role of genetics in intrinsic skin aging, or about its potential to influence intrinsic factors (apart from healthy nutrition and lifestyle), extrinsic skin aging occurs mainly due to the cumulative exposure to ultraviolet radiation [5]. Therefore, the best prevention from skin aging is apparently optimal sun protection. karger@karger.com

(C) 2020 S. Karger AG, Basel

www.karger.com/drm

Karger ${ }^{\prime}=$
Laurence Imhof

Department of Dermatology

University Hospital Zurich

Gloriastrasse 31, CH-8091 Zurich (Switzerland)

laurence.Imhof@usz.ch 


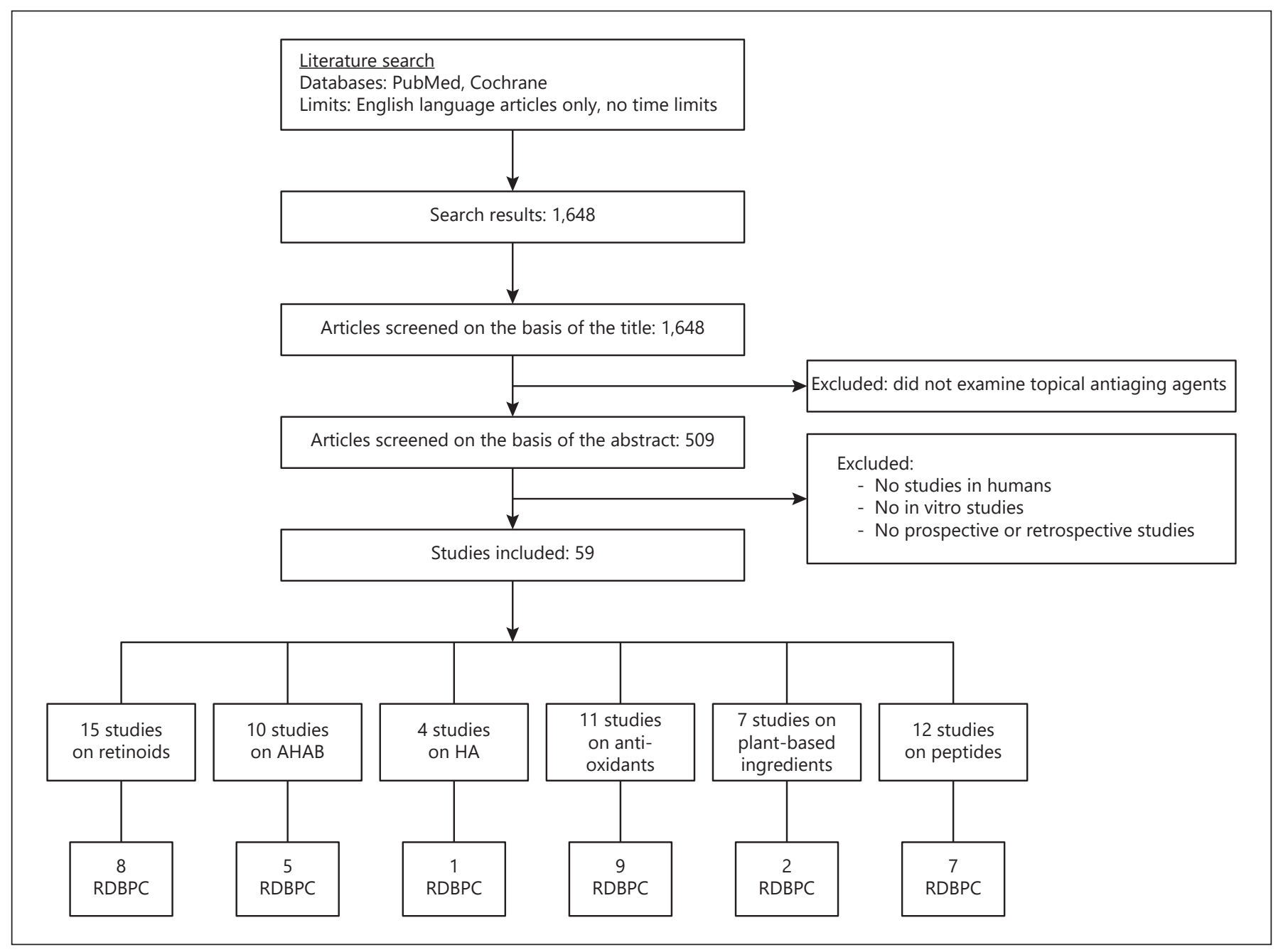

Fig. 1. Flowchart of the Materials and Methods flow diagram of the search and selection process according to Preferred Reporting Items for Systematic Reviews and Meta-Analysis. AHA, a-hydroxy acids; HA, hyaluronic acid; RDBPC, randomized, double-blind, placebo-controlled study.

A vast array of cosmeceuticals is available on the market to reduce signs of skin aging. These cosmetic products claim to have biologically active ingredients with medicinal or drug-like benefits. Evidence and good clinical practice of the data supporting their use are often lacking. This article reviews the evidence available in the published literature which supports the use of ingredients most commonly used in cosmeceuticals, with a special focus on in vivo studies.

\section{Materials and Methods}

For further details, see the online supplementary material (see www.karger.com/doi/10.1159/000509296; Fig. 1).

\section{Results}

\section{Retinoids}

Retinoids are natural or synthetic derivates of vitamin A. The naturally occurring vitamin A (retinol) is oxidized reversibly to retinaldehyde, which in turn is oxidized irreversibly to the biologically active form - retinoic acid (tretinoin) [6].

Retinoids have been applied topically and systemically to treat skin diseases - in particular acne vulgaris - since the 1940s. Their antiaging effect has been propagated since the 1980s [7].

The antiaging-specific mechanism of action is based on its interaction with the retinoic acid receptor in the nucleus which leads to an increase in collagen concentra- 
Table 1. Human studies on topical retinoids [10, 74-87]

\begin{tabular}{|c|c|c|c|c|}
\hline Study & Study design & $n$ & Treatment $\operatorname{arm}(\mathrm{s})$ & Efficacy \\
\hline \multicolumn{5}{|c|}{ Retinol (vitamin A) } \\
\hline $\begin{array}{l}\text { Pierard- } \\
\text { Franchimont } \\
\text { et al. [74] }\end{array}$ & $\begin{array}{l}\mathrm{R}, \mathrm{DB}, \mathrm{PC} \\
\mathrm{PG}\end{array}$ & 120 & $\begin{array}{l}4 \text { randomized groups of } 30 \text { subjects receiving } \\
\text { either (1) } 0.04 \% \text { retinol, (2) } 1 \% \text { melibiose }+4 \% \\
\text { lactose, (3) } 0.04 \% \text { retinol }+1 \% \text { melibiose }+4 \% \\
\text { lactose, or (4) } 1 \% \text { salicylic acid }\end{array}$ & $\begin{array}{l}\text { Significant differences in efficacy and lingering activity assessed by Cutometer } \\
\text { and image analysis after optical shadowing }\end{array}$ \\
\hline $\begin{array}{l}\text { Varani } \\
\text { et al. }[75]\end{array}$ & PC, RL & 53 & $1 \%$ topical retinol vs. vehicle control & $\begin{array}{l}\text { Statistically significant histological improvement on day } 7 \text { (increase in fibroblast } \\
\text { growth and collagen synthesis and reduction in matrix-degrading matrix } \\
\text { metalloproteinase levels) }\end{array}$ \\
\hline $\begin{array}{l}\text { Kafi } \\
\text { et al. [76] }\end{array}$ & $\begin{array}{l}\mathrm{R}, \mathrm{DB}, \mathrm{PC} \\
\mathrm{RL}\end{array}$ & 36 & $\begin{array}{l}\text { Topical } 0.4 \% \text { retinol lotion vs. its vehicle up to } 3 \\
\text { times/week for } 24 \text { weeks }\end{array}$ & $\begin{array}{l}\text { Significant differences between retinol- and vehicle-treated skin in fine wrinkle } \\
\text { scores }(p<0.001) \text {; retinol treatment significantly increased glycosaminoglycan } \\
\text { expression }(p=0.02) \text { and procollagen I immunostaining }(p=0.049)\end{array}$ \\
\hline $\begin{array}{l}\text { Kang } \\
\text { et al. [77] }\end{array}$ & $\begin{array}{l}\text { R, DB, PG, } \\
\text { PC }\end{array}$ & 30 & $\begin{array}{l}\text { Topical retinol vs. retinoic acid vs. vehicle } \\
\text { control }\end{array}$ & $\begin{array}{l}\text { Retinol produced from none to only trace erythema, which was clinically and sta- } \\
\text { tistically insignificant, whereas retinoic acid induced a significant } 3.7 \text {-fold increase } \\
\text { in erythema score vs. vehicle }(n=10, p<0.01) \text {; however, retinol induces epidermal } \\
\text { thickening and enhances CRABP II and CRBP mRNA and protein expression }\end{array}$ \\
\hline $\begin{array}{l}\text { Randhawa } \\
\text { et al. [78] }\end{array}$ & $\mathrm{R}, \mathrm{DB}, \mathrm{PC}$ & 62 & $\begin{array}{l}\text { Retinol formulation vs. its vehicle to full face for } \\
52 \text { weeks }\end{array}$ & $\begin{array}{l}\text { The retinol group showed significant photodamage improvement over vehicle } \\
\text { at all time points during the study; after } 52 \text { weeks, retinol had improved crow's } \\
\text { feet fine lines by } 44 \% \text {, and mottled pigmentation by } 84 \% \text {, with over } 50 \% \text { of } \\
\text { subjects showing }+2 \text { grades of improvement in many parameters; additionally, } \\
\text { at week } 52 \text {, histochemical data confirmed the clinical results, showing increased } \\
\text { expression of type I procollagen, hyaluronan, and Ki67 compared to vehicle }\end{array}$ \\
\hline
\end{tabular}

\section{Retinaldehyde}

\begin{tabular}{llll}
\hline $\begin{array}{l}\text { Saurat } \\
\text { et al. [79] }\end{array} \quad$ R, PC, RL 229 & $\begin{array}{l}\text { 0.5, 0.1, or 0.05\% retinaldehyde for } 1-3 \text { months } \\
\text { on one forearm and a vehicle control on the } \\
\text { other }\end{array}$
\end{tabular}

Significant dose-dependent increase in epidermal thickness/keratin 14 immunoreactivity; at a high concentration $(0.5 \%)$, the morphological changes noted were similar to those induced by $<0.1 \%$ topical retinoic acid; improved tolerance with decreasing concentration could be shown

\begin{tabular}{lll}
\hline Creidi & MC, DB, PC, 125 & $\begin{array}{l}\text { Topical retinaldehyde (0.05\%), retinoic acid } \\
\text { (0.05\%), or vehicle control for 44 weeks once per } \\
\text { et al. [10] }\end{array}$ \\
day & PG & $\begin{array}{l}\text { Retinaldehyde and retinoic acid had similar improvements in profilometric } \\
\text { scores at } 18 \text { and } 44 \text { weeks; retinaldehyde was better tolerated throughout the } \\
\text { study period }\end{array}$
\end{tabular}

Tretinoin (retinoic acid)

\begin{tabular}{llll}
\hline $\begin{array}{l}\text { Maddin } \\
\text { et al. [80] }\end{array}$ & MC, DB, PC & 800 & $\begin{array}{l}0.1 \% \text { isotretinoin vs. vehicle cream applied on } \\
\text { face, forearms, and hands }\end{array}$ \\
\hline $\begin{array}{l}\text { Weinstein } \\
\text { et }\end{array}$ & MC, R, DB, & 251 & $\begin{array}{l}\text { Topical tretinoin at } 0.05 \% \text { or } 0.01 \% \text { vs. vehicle } \\
\text { T }\end{array}$
\end{tabular}

et al. [81] PC control sallowness, and texture on clinical evaluation

Significant improvement in fine wrinkling, mottled hyperpigmentation, roughness, laxity, and epidermal thickness in the group treated with $0.05 \%$ tretinoin vs. $0.01 \%$ and vehicle groups; dose-dependent responses but no effect on dermal thickness, collagen regeneration, or reversal of keratinocyte atypia

\begin{tabular}{llll}
\hline Olsen & MC, R, DB, 298 & $\begin{array}{l}\text { Once daily application of either } 0.05 \% \text { or } 0.01 \% \\
\text { tretinoin emollient cream vs. vehicle cream for a }\end{array}$ & $\begin{array}{l}\text { Significant improvement in histological and clinical markers in both the } 0.05 \\
\text { and } 0.01 \% \text { tretinoin group as compared with vehicle }\end{array}$
\end{tabular}

et al. [82] PC tretinoin emollient cream vs. vehicle cream for a and $0.01 \%$ tretinoin group as compared with vehicle

Leyden $\quad$ R, DB, PC ? $\quad 0.05 \%$ tretinoin cream vs. vehicle control once

et al. [83] daily in the treatment of photodamaged facial

Significant amelioration of many signs of photodamage were achieved with minimal side effects; fine and coarse wrinkling, sallowness, looseness, and hyperpigmentation were significantly improved with tretinoin therapy; an objective method based on digital image processing of silicone rubber casts obtained from the crow's-feet area also indicated that the skin surface topography was smoother and less wrinkled in the tretinoin-treated group than the vehicle-control group

\begin{tabular}{lllll}
\hline $\begin{array}{l}\text { Olsen } \\
\text { et al. [84] }\end{array}$ & MC, R, DB, 296 & $\begin{array}{l}\text { Tretinoin at 0.05, 0.01, or 0.001\% in an emollient } \\
\text { cream formulation vs. vehicle in the treatment of } \\
\text { photodamaged facial skin for 24 weeks }\end{array}$ & $\begin{array}{l}\text { Tretinoin emollient cream 0.05\% appears to be safe and effective in the } \\
\text { treatment of photodamaged skin }\end{array}$ \\
\hline $\begin{array}{l}\text { Sendagorta } \\
\text { et al. [85] }\end{array}$ & MC, R, PC & 776 & $\begin{array}{l}\text { 36 weeks of treatment with either vehicle cream } \\
\text { or isotretinoin cream, applied once nightly }\end{array}$ & $\begin{array}{l}\text { Treatment with isotretinoin resulted in statistically significant improvement in } \\
\text { overall appearance, fine wrinkling, discrete pigmentation, sallowness, and } \\
\text { texture; isotretinoin cream was well tolerated }\end{array}$ \\
\hline $\begin{array}{l}\text { Ellis } \\
\text { et al. [86] }\end{array}$ & R, SB, PC & 30 & 4 months of treatment with topical tretinoin & $\begin{array}{l}\text { Statistically significant improvement in fine and coarse wrinkling and skin texture; } \\
\text { the number of discrete lentigines decreased by 71\% vs. before therapy; histologi- } \\
\text { cally, there was a statistically significant thickening of the epidermis; side effects } \\
\text { were limited to a cutaneous retinoid reaction that diminished as therapy proceeded }\end{array}$ \\
\hline $\begin{array}{l}\text { Kang } \\
\text { et al. [87] }\end{array}$ & MC, R, PC & 204 & $\begin{array}{l}\text { Tretinoin vs. vehicle emollient cream applied to } \\
\text { the entire face once a day for up to 2 years }\end{array}$ & $\begin{array}{l}\text { Long-term treatment with tretinoin emollient cream 0.05\% is safe and effective } \\
\text { in subjects with moderate-to-severe facial photodamage }\end{array}$
\end{tabular}

DB, double blind; MC, multicenter; $n$, number of participants; PC, placebo controlled; PG, parallel group; R, randomized; RL, right-left comparison; SB, single blind. 
tion in the dermis, keratinization of the epidermis, and inhibition of UV-induced MMP production [8]. Additionally, retinoids are able to inhibit tyrosinase, which reduces hyperpigmentation [9].

Various retinoids have been studied for the treatment of aging skin. Table 1 gives an overview of the clinical studies with good evidence of clinical and/or histological improvement in aging skin by retinoids. Precursor forms of tretinoin, such as retinol and retinaldehyde, are commonly used in cosmeceuticals. They were shown to have fewer side effects than tretinoin, the biologically active form. The latter has the best evidence to reduce signs of aging skin (Table 1). Tretinoin is only available on prescription, as it can cause significant side effects such as erythema, xerosis, desquamation, and pruritus. Randomized trials have shown comparable antiaging effects of retinol and retinaldehyde compared to tretinoin $[9,10]$. However, as retinol needs to be converted into tretinoin in vivo to become biologically active, it has been speculated that retinol is 20 -fold less effective than tretinoin [11]. Additionally, as retinol is extremely unstable and easily gets degraded on exposure to light and air, an appropriate vehicle needs to be used in creams to elicit its efficacy [12].

\section{$\alpha$-Hydroxy Acids}

a-Hydroxy acids (AHAs) are widely used in chemical peeling and cosmetic formulations. There are several AHA types, with the most often used being glycolic, citric, lactic, pyruvic, mandelic, and tartaric acids [13].

Its exact mechanism of action has not yet been fully clarified. According to the literature, they increase the water retention capacity at the epidermal level, cause desquamation and softening, as well as normalization of the differentiation by influencing intracellular ion binding $[14,15]$. At the level of the dermis, dose-dependent increases in fibroblast proliferation, collagen production, and glycosaminoglycan synthesis have been described [16].

The beneficial effects were histologically proven in individual studies [17-19]. In these studies, clinical effects included increases in skin firmness and thickness, improvement in skin texture, and reduction in fine wrinkles.

\section{Hyaluronic Acid}

Hyaluronic acid (HA), a nonsulfated glycosaminoglycan, is composed of repeating units of polymeric disaccharides of D-glucuronic acid and N-acetyl-D-glucosamine linked by a glucuronidic $\beta(1 \rightarrow 3)$ bond. It is widely used in esthetic medicine. Due to its structure, it has a remarkable water-holding ability. Consequently, it improves tissue hydration. In addition, skin hydration and antioxidant effects of HA promote cell regeneration and stimulate the production of collagen [20].

The percutaneous absorption of HA, across the stratum corneum, is dependent on its molecular weight. Depending on the chain length, it is categorized as small-size HA fragments (HAFs; $<50 \mathrm{kDa}$ ), intermediate-size HA fragments (HAFi; 50-400 kDa), and large-size HA fragments (HAFl; $>400 \mathrm{kDa}$ ) [21].

Experimental studies have shown that topically applied HAFs and HAFi are able to penetrate the epidermis, but only HAFi were able to induce cellular proliferation within the epidermal and dermal compartments in vivo [21]. A vehicle-controlled study by Kaya et al. [21] showed histologically an increase in human skin thickness in response to HAFi accompanied by a clear clinical improvement in patients with skin atrophy. In contrast, the same concentration of HAFl and HAFs applied to the same patients had no effect on skin thickness.

In another trial, 76 female patients with periocular wrinkles were administered a $0.1 \%$ cream formulation containing HA of different molecular weights twice daily for a period of 60 days. All HA-based creams demonstrated a significant improvement in skin hydration and overall elasticity values when compared to placebo. However, a significant reduction in wrinkle depth was only observed in the women treated with a cream formulation containing low-molecular-weight HA (50 and $130 \mathrm{kDa}$ ) [22].

Additional human clinical studies on skin rejuvenation by topically applied HA are listed in Table 2 .

\section{Antioxidants}

Substances with antioxidant activity find great application in cosmeceuticals. Their effect is based on the neutralization of free radicals (ROS), which are responsible for the degradation of collagen fibers. Most commonly applied antioxidants are vitamins, which are able to penetrate the skin barrier due to their low molecular weight. Table 3 (antioxidants) gives an overview of the most precisely studied substances used in cosmeceuticals with antioxidant properties.

\section{Niacinamide (Vitamin $\mathrm{B}_{3}$ )}

Niacinamide, also known as nicotinamide, is part of the niacin coenzymes NAD+, NADP+, and their reduced forms NADH and NADPH. Among others, these coenzymes play a role in DNA synthesis and repair. Surjana et al. [23] demonstrated that niacinamide increases DNA 
Table 2. Human studies on $\alpha$-hydroxy acids and hyaluronic acid [17-19, 21, 88-97]

\begin{tabular}{|c|c|c|c|c|}
\hline Study & Study design & $n$ & Treatment $\operatorname{arm}(\mathrm{s})$ & Efficacy \\
\hline \multicolumn{5}{|c|}{$\alpha$-Hydroxy acid: glycolic acid } \\
\hline $\begin{array}{l}\text { Newman } \\
\text { et al. [17] }\end{array}$ & $\begin{array}{l}\mathrm{R}, \mathrm{DB}, \mathrm{PC} \\
\mathrm{RL}\end{array}$ & 41 & $\begin{array}{l}\text { Glycolic acid ( } 50 \%) \text { or vehicle was applied } \\
\text { topically for } 5 \text { min to one side of the face, } \\
\text { forearms, and hands, once weekly for } 4 \text { weeks; } \\
\text { punch biopsies were taken before therapy and at } \\
5 \text { weeks for histologic study }\end{array}$ & $\begin{array}{l}\text { Reduction in fine wrinkles and solar keratosis, improvement in skin texture; } \\
\text { histologically reduction in corneal layer, epidermal thickening; } \\
\text { some samples show collagen thickening }\end{array}$ \\
\hline $\begin{array}{l}\text { Thibault } \\
\text { et al. [88] }\end{array}$ & $\mathrm{R}, \mathrm{DB}, \mathrm{PC}$ & 75 & $\begin{array}{l}5 \% \text { glycolic acid cream vs. the placebo cream to } \\
\text { the face and neck for a period of } 3 \text { months }\end{array}$ & $\begin{array}{l}\text { Overall, there was a trend toward greater improvement or less worsening in the } \\
\text { glycolic acid group for all for photoaging clinically; statistically significant } \\
\text { improvement favoring the active cream in general skin texture and } \\
\text { discoloration, and a nonsignificant trend favoring glycolic acid in the reduction } \\
\text { of wrinkles }\end{array}$ \\
\hline
\end{tabular}

\begin{tabular}{llll}
\hline$\alpha$-Hydroxy acid: glycolic acid, lactic acid, citric acid \\
\hline $\begin{array}{l}\text { Ditre } \\
\text { et al. [18] }\end{array}$ & R, PC, PG, & 17 & $\begin{array}{l}\text { Glycolic acid 25\% }(n=5) \text {, lactic acid }(n=5), \\
\text { citric acid }(n=7) \text { vs. placebo, application on } \\
\text { forearms for 6 months }\end{array}$ \\
\hline $\begin{array}{l}\text { Stiller } \\
\text { et al. [89] }\end{array}$ & R, DB, PC & 74 & $\begin{array}{l}\text { Glycolic acid, L-lactic acid, or vehicle creams } \\
\text { were applied twice daily to the face and outer }\end{array}$
\end{tabular}

et al. [89] were applied twice daily to the face and outer aspect of the forearms for 22 weeks

$25 \%$ increase in skin thickness and reduction in melanin content on the verum side

More patients in the $8 \%$ glycolic acid or $8 \%$ L-lactic acid group improved at least 1 grade (on a scale from 0 to 9 ) in overall photodamage severity on the face than in the vehicle group (76\% glycolic acid, $71 \%$ lactic acid, and $40 \%$ vehicle; $p<0.05$ ); on the forearms, after 22 weeks, treatment with glycolic acid was superior to the vehicle in improving the overall severity of photodamage and sallowness $(p<$ $0.05)$; L-lactic acid cream was significantly superior to the vehicle in reducing the overall severity of photodamage $(p<0.05)$, mottled hyperpigmentation $(p<0.05)$, sallowness $(p<0.05)$, and roughness on the forearms $(p<0.05)$ at week 22

\begin{tabular}{|c|c|c|c|c|}
\hline \multicolumn{5}{|l|}{ Lactic acid } \\
\hline Smith [19] & OL, PG & 24 & $\begin{array}{l}12 \%(n=14) \text { or } 5 \%(n=10) \text { lactic acid test } \\
\text { solutions twice a day to the full face, except the } \\
\text { eyelids for } 3 \text { months }\end{array}$ & $\begin{array}{l}\text { Increased firmness and thickness of the epidermis and dermis; } \\
\text { clinical improvement in skin texture and the appearance of fine lines and } \\
\text { wrinkles }\end{array}$ \\
\hline \multicolumn{5}{|c|}{ Mandelic acid } \\
\hline $\begin{array}{l}\text { Jacobs } \\
\text { et al. }[90\}\end{array}$ & OL, PG & 24 & $\begin{array}{l}\text { Mandelic acid ( } 4 \text { and } 6 \% \text { ) applied topically to the } \\
\text { face twice a day for } 4 \text { weeks }\end{array}$ & $\begin{array}{l}\text { Significant increase in skin firmness and elasticity of the lower eyelid } \\
\text { (cutometer); improvement in fine lines of the lower eyelid (subjectively) }\end{array}$ \\
\hline \multicolumn{5}{|c|}{$\alpha$-Lipoic acid (ALA) } \\
\hline $\begin{array}{l}\text { El-Komy } \\
\text { et al. [91] }\end{array}$ & $\mathrm{SB}, \mathrm{PC}, \mathrm{RL}$ & 20 & $\begin{array}{l}5 \% \text { ALA on right half of the face and placebo gel } \\
\text { on left half, twice daily for } 6 \text { months }\end{array}$ & $\begin{array}{l}\text { Mean epidermal thickness significantly increased on the verum side; mean dermal } \\
\text { thickness increased more (nonsignificant) on the verum side vs. the placebo side }\end{array}$ \\
\hline $\begin{array}{l}\text { Beitner } \\
{[92]}\end{array}$ & $\begin{array}{l}\mathrm{R}, \mathrm{PC}, \mathrm{DB} \\
\mathrm{RL}\end{array}$ & 33 & $\begin{array}{l}\text { Half of the face treated with } 5 \% \text { ALA cream and } \\
\text { other half with control cream, twice daily for } 12 \\
\text { weeks }\end{array}$ & $\begin{array}{l}\text { Statistically significant improvement in photoaging on the ALA-treated half of } \\
\text { the face }\end{array}$ \\
\hline $\begin{array}{l}\text { Perricone } \\
{[93]}\end{array}$ & $\mathrm{OL}$ & 15 & $5 \%$ ALA on the face twice daily for 12 weeks & $\begin{array}{l}\text { Overall, } 50 \% \text { reduction in facial lines; marked improvement in fine lines; } \\
\text { improved texture and decreased discoloration }\end{array}$ \\
\hline $\begin{array}{l}\text { Sherif } \\
\text { et al. [94] }\end{array}$ & $\begin{array}{l}\mathrm{R}, \mathrm{DB}, \mathrm{PC} \\
\mathrm{RL}\end{array}$ & 12 & $\begin{array}{l}5 \% \text { ALA on the right half of the face and a } \\
\text { placebo gel on the left half twice daily for } 3 \\
\text { months }\end{array}$ & $\begin{array}{l}\text { Visible reduction in the depth of fine periorbital lines and fine vertical lines on } \\
\text { the upper lip; deeper periorbital lines appeared shallow; increase in dermal } \\
\text { density (ultrasound) }\end{array}$ \\
\hline \multicolumn{5}{|c|}{ Hyaluronic acid (HA) } \\
\hline $\begin{array}{l}\text { Pavicic } \\
\text { et al. [95] }\end{array}$ & $\begin{array}{l}\mathrm{R}, \mathrm{DB}, \mathrm{PC} \\
\mathrm{RL}\end{array}$ & 76 & $\begin{array}{l}\text { HA cream } 0.1 \%(\mathrm{w} / \mathrm{w})(50,130,300,800 \text {, and } \\
2,000 \mathrm{kDa} \text {, respectively) twice daily on periocular } \\
\text { wrinkles for } 60 \text { days }\end{array}$ & $\begin{array}{l}\text { Significant improvement in skin hydration level; remarkable improvement in } \\
\text { skin elasticity; significant reduction in wrinkle depth due to better penetration } \\
\text { abilities of low-molecular-weight HA }\end{array}$ \\
\hline $\begin{array}{l}\text { Jegasothy } \\
\text { et al. [96] }\end{array}$ & $\mathrm{R}, \mathrm{SB}$ & 33 & $\begin{array}{l}\text { Nano-hyaluronic acid in a cream, serum, and } \\
\text { lotion; } 8 \text { weeks of treatment in the periorbital } \\
\text { region }\end{array}$ & $\begin{array}{l}\text { Significant improvement in moisturizing effect of the product range and skin } \\
\text { elasticity; skin roughness improved remarkably }\end{array}$ \\
\hline $\begin{array}{l}\text { Kaya } \\
\text { et al. }[21]\end{array}$ & PC & $\begin{array}{l}6 \mathrm{P} \\
17 \mathrm{C}\end{array}$ & $\begin{array}{l}\text { Daily topical application to the forearm of a } \\
1 \% \text { preparation of intermediate-size HA } \\
\text { fragments for } 1 \text { month }\end{array}$ & $\begin{array}{l}\text { None of the control participants revealed a measurable increase in skin } \\
\text { thickness; by contrast, all } 6 \text { patients with skin atrophy (either age-related or } \\
\text { associated with corticosteroid therapy) developed marked skin thickening } \\
\text { following topical application of intermediate-size HA fragments }\end{array}$ \\
\hline $\begin{array}{l}\text { Poetschke } \\
\text { et al. } \\
{[97]}\end{array}$ & OL, PG & 20 & $\begin{array}{l}\text { Four groups, each with a different anti-wrinkle } \\
\text { cream containing HA (Balea, Nivea, Lancôme, } \\
\text { Chanel), daily use, 3-month trial }\end{array}$ & $\begin{array}{l}\text { Significant reduction in perioral and orbital wrinkle depth and remarkable } \\
\text { increase in skin tightness in all groups; minimal significant changes in skin } \\
\text { elasticity in individual groups }\end{array}$ \\
\hline
\end{tabular}


Table 3. Human studies on topical antioxidants [24-26, 29-33, 35, 36, 39]

\begin{tabular}{|c|c|c|c|c|}
\hline Study & Study design & $n$ & Treatment $\operatorname{arm}(\mathrm{s})$ & Efficacy \\
\hline \multicolumn{5}{|c|}{ Niacinamide $\left(B_{3}\right)$} \\
\hline $\begin{array}{l}\text { Kawada } \\
\text { et al. [24] }\end{array}$ & $\mathrm{R}, \mathrm{DB}, \mathrm{PC}, \mathrm{RL}$ & 30 & Nicotinamide $4 \%$ cream vs. placebo for 8 weeks & $\begin{array}{l}\text { Significant improvement in skin wrinkles }(p<0.001) \text { and skin texture }(p< \\
0.05)\end{array}$ \\
\hline $\begin{array}{l}\text { Bissett } \\
\text { et al. [25] }\end{array}$ & $\mathrm{R}, \mathrm{DB}, \mathrm{PC}, \mathrm{RL}$ & 50 & Nicotinamide cream $5 \%$ vs. placebo for 12 weeks & $\begin{array}{l}\text { Skin improvement overall and improvement in skin elasticity in the } \\
\text { nicotinamide group }\end{array}$ \\
\hline $\begin{array}{l}\text { Bissett } \\
\text { et al. [26] }\end{array}$ & $\mathrm{R}, \mathrm{DB}, \mathrm{PC}, \mathrm{RL}$ & 50 & $\begin{array}{l}\text { Moisturizer control product vs. the same } \\
\text { moisturizer product containing } 5 \% \text { niacinamide } \\
\text { for } 12 \text { weeks }\end{array}$ & $\begin{array}{l}\text { Niacinamide significantly improved fine lines/wrinkles, hyperpigmentation } \\
\text { spots, texture, and red blotchiness vs. control }\end{array}$ \\
\hline \multicolumn{5}{|c|}{$L$-Ascorbic acid (vitamin $C$ ) } \\
\hline $\begin{array}{l}\text { Humbert } \\
\text { et al. [33] }\end{array}$ & $\mathrm{R}, \mathrm{DB}, \mathrm{PC}$ & 20 & $5 \%$ vitamin $\mathrm{C}$ cream vs. vehicle for 6 months & $\begin{array}{l}\text { Significant increase in the density of skin microrelief and a decrease in deep } \\
\text { furrows; ultrastructural evidence of elastic tissue repair }\end{array}$ \\
\hline $\begin{array}{l}\text { Nusgens } \\
\text { et al. [29] }\end{array}$ & $\mathrm{R}, \mathrm{DB}, \mathrm{PC}, \mathrm{RL}$ & 10 & $\begin{array}{l}5 \% \text { L-ascorbic acid in glycerol vs. glycerol alone } \\
\text { for } 6 \text { months daily (right vs. left arm) }\end{array}$ & $\begin{array}{l}\text { Collagen type I and III mRNAs were increased to a similar extent by vitamin } \\
\text { C in skin biopsies }\end{array}$ \\
\hline $\begin{array}{l}\text { Raschke } \\
\text { et al. [30] }\end{array}$ & $\mathrm{R}, \mathrm{DB}, \mathrm{PC}, \mathrm{RL}$ & 23 & $\begin{array}{l}3 \% \text { vitamin } \mathrm{C} \text { cream and placebo cream each on } \\
\text { one half of the face (split-face design) twice daily } \\
\text { for } 12 \text { weeks }\end{array}$ & $\begin{array}{l}\text { After } 1 \text { month, a significant increase in the number of dermal papillae was } \\
\text { demonstrated by confocal laser scanning microscope; significant reduction in } \\
\text { facial wrinkles after } 12 \text { weeks }\end{array}$ \\
\hline $\begin{array}{l}\text { Fitzpatrick } \\
\text { and } \\
\text { Rostan [31] }\end{array}$ & $\mathrm{R}, \mathrm{DB}, \mathrm{PC}, \mathrm{RL}$ & 10 & $\begin{array}{l}\text { Vitamin C complex having } 10 \% \text { ascorbic acid } \\
\text { (water soluble) and } 7 \% \text { tetrahexyldecyl ascorbate } \\
\text { (lipid soluble) in an anhydrous polysilicone gel } \\
\text { base to one-half of the face and the inactive } \\
\text { polysilicone gel base to the opposite side for } 12 \\
\text { weeks }\end{array}$ & $\begin{array}{l}\text { Biopsies showed increased grenz zone collagen, as well as increased staining } \\
\text { for collagen type I mRNA; significant improvement in the vitamin C-treated } \\
\text { side was seen in the decreased photoaging scores of the cheeks }(p=0.006) \text { and } \\
\text { peri-oral area }(p=0.01) \text {. }\end{array}$ \\
\hline $\begin{array}{l}\text { Haftek } \\
\text { et al. [32] }\end{array}$ & $\mathrm{R}, \mathrm{DB}, \mathrm{RL}$ & 20 & $\begin{array}{l}5 \% \text { stabilized vitamin } \mathrm{C} \text { and } 0.1 \% \text { madecassoside } \\
\text { (Remederm) vs. Toleriane for } 6 \text { months twice } \\
\text { daily half }\end{array}$ & $\begin{array}{l}\text { Significant improvement in the clinical score for deep and superficial } \\
\text { wrinkles, suppleness, firmness, roughness, and skin hydration; in } 2 / 3 \text { of the } \\
\text { subjects, re-appearance of a normally structured elastic fiber network in skin } \\
\text { biopsy }\end{array}$ \\
\hline \multicolumn{5}{|l|}{ Vitamin E } \\
\hline $\begin{array}{l}\text { Murray } \\
\text { et al. [35] }\end{array}$ & $\mathrm{R}, \mathrm{PC}, \mathrm{DB}, \mathrm{RL}$ & 9 & $\begin{array}{l}\text { 15\% vitamin C, } 1 \% \text { vitamin E, and ferulic acid } \\
\text { and its vehicle vs. vehicle only were applied to } \\
\text { separate patches of normal-appearing human } \\
\text { skin for } 4 \text { days; each patch was irradiated with } \\
\text { solar-simulated UV, } 2-10 \text { minimal erythema } \\
\text { doses; } 1 \text { day later, the skin was evaluated for } \\
\text { erythema and sunburn cells, and immuno- } \\
\text { histochemically for thymine dimers and p53 }\end{array}$ & $\begin{array}{l}\text { Significant and meaningful photoprotection; } \\
\text { particularly effective for reducing thymine dimer mutations known to be } \\
\text { associated with skin cancer }\end{array}$ \\
\hline $\begin{array}{l}\text { Lin } \\
\text { et al. [36] }\end{array}$ & $\begin{array}{l}\text { Not further } \\
\text { specified }\end{array}$ & & $\begin{array}{l}\text { Aliquots of vehicle; } 0.5 \% \text { trans-ferulic acid; } 15 \% \\
\text { L-ascorbic acid, } 1 \% \text { DL- } \alpha \text {-tocopherol, and } 15 \% \\
\text { L-ascorbic acid, } 1 \% \text { DL- } \alpha \text {-tocopherol, and } 0.5 \% \\
\text { trans-ferulic acid were applied to patches of back } \\
\text { skin daily for } 4 \text { days; a } 1,000 \text {-W solar simulator } \\
\text { delivered UV radiation to the skin surface; } \\
\text { evaluation was carried out } 24 \text { h later }\end{array}$ & $\begin{array}{l}\text { Doubled photoprotection to solar-simulated skin irradiation from } 4 \text { - to } \\
\text { approximately } 8 \text {-fold measured by both erythema and sunburn cell formation; } \\
\text { inhibition of apoptosis was associated with reduced induction of caspase- } 3 \\
\text { and caspase-7 }\end{array}$ \\
\hline \multicolumn{5}{|l|}{ CoQ10 } \\
\hline $\begin{array}{l}\text { Inui } \\
\text { et al. [39] }\end{array}$ & $\mathrm{R}, \mathrm{DB}, \mathrm{PC}$ & $31 \mathrm{f}$ & $\begin{array}{l}1 \% \mathrm{CoQ}_{10} \text { cream or placebo cream twice daily } \\
\text { for } 3 \text { months }\end{array}$ & $\begin{array}{l}\text { Reduction in the wrinkle score in the } 1 \% \mathrm{CoQ}_{10} \text { group after } 5 \text { months vs. no } \\
\text { reduction in the control }\end{array}$ \\
\hline
\end{tabular}

excision repair and enhances repair of UVB radiationinduced cyclobutane pyrimidine dimers and UVA radiation-induced 8-oxo-7,8-dihydro-2'-deoxyguanosine. Multiple randomized, placebo-controlled trials have shown clinical improvement in skin texture, elasticity, and wrinkles after 12 weeks of daily application of cream containing 5\% niacinamide [24-26]. However, clinical trials with more participants need to be conducted to determine its applicability as a definitive treatment for photoaging.

\section{L-Ascorbic Acid (Vitamin C)}

Vitamin C, also known as ascorbic acid, plays a critical role in collagen and elastin synthesis as it is a cofactor for 
both prolyl and lysyl hydroxylases, which catalyze the formation of hydroxyproline and hydroxylysine [27]. The hydroxylation of proline and lysine facilitates the excretion of procollagen from fibroblasts. Its effect as antioxidant in the skin is based on the modulation of the UVinduced ROS damage [28].

Effectiveness of vitamin $\mathrm{C}$ in concentrations of up to $15 \%$ was shown in several double-blind, placebo-controlled studies [29-33]. The increase in collagens I and III was also observed histologically after use of vitamin C [29]. However, the clinical studies conducted so far included low participant numbers; thus, placebo-controlled trials with higher numbers of participants are necessary to confirm the promising clinical results seen in earlier studies.

Ascorbic acid requires an acidic environment for optimal absorption and oxidizes very quickly when exposed to light and air. This problem has been partially overcome by chemically modifying ascorbic acid by esterification of its hydroxyl group.

\section{D- $\alpha$-Tocopherol (Vitamin E)}

$\mathrm{D}-\alpha$-Tocopherol is the synthetic form of vitamin $\mathrm{E}$ which is found in commercial preparations. It acts as antioxidant within cell membranes where it protects polyunsaturated fatty acids from free radicals. Vitamin E also works as a direct antioxidant by donating electrons to singlet oxygen and superoxide anions. Ascorbic acid and glutathione are both essential for the sustained action of vitamin $\mathrm{E}$ as they donate necessary hydrogen ions when the tocopherol radical is formed. In vitro experiments have shown a reduction in MMP-1 transcription after fibroblasts from older individuals were incubated with $\mathrm{D}$ - $\alpha$-tocopherol. MMP-1 is normally elevated in older persons compared with younger individuals [34]. Increase in MMP-1 levels leads to collagen breakdown and the destruction of supportive matrix [4]. In vivo, vitamin E has been studied as a sun protectant $[35,36]$. Pretreatment of hairless mice skin with $5 \%$ tocopherol before UVB exposure resulted in a $75 \%$ decrease in the severity of skin wrinkling and a significant decrease in skin tumor formation [37].

As ascorbic acid is needed to maintain active vitamin $\mathrm{E}$ stores, the combined effect of vitamins $\mathrm{C}$ and $\mathrm{E}$ has also been studied. The topical use of vitamins $\mathrm{C}$ and $\mathrm{E}$ combined before UV irradiation decreased erythema, cytokine production, thymine dimer formation, and p53 upregulation [35]. Additionally, it was shown that ferulic acid (a botanical agent) could reduce the oxidative stress 4 -fold when added to formulations containing vitamins
$\mathrm{C}$ and $\mathrm{E}$ [36]. Data supporting any effect of vitamin $\mathrm{E}$ in topical therapies by improvements in skin wrinkling, discoloration, or texture, however, are still lacking.

\section{Coenzyme Q10}

Coenzyme Q $\left(\mathrm{CoQ}_{10}\right)$ was discovered in 1957 by Frederick Crane. The name coenzyme Q10 derives from its chemical structure, a benzoquinone ring with a side chain composed of 10 isoprene units. The structure is similar to some vitamins (e.g., vitamin $\mathrm{K}$ ); however, $\mathrm{CoQ}_{10}$ is not a vitamin since it is synthesized in the body, whereas vitamins must be obtained from the diet.

It has a fundamental role in cellular bioenergetics as a cofactor for mitochondrial enzyme complexes involved in the oxidative phosphorylation and production of adenosine triphosphate (ATP). Beside this, $\mathrm{CoQ}_{10}$ serves as an antioxidant or free radical scavenger, and is able to stimulate collagen production [38]. Its application in different illnesses is being discussed but not yet established. So far, one placebo-controlled double-blind study could show wrinkle improvement after application of $1 \% \mathrm{CoQ}_{10}$ cream [39]. Furthermore, it was shown in vitro that it reduces MMP activity [39].

\section{Plant-Based Ingredients}

Phenols

Phenols are aromatic organic compounds found in many plants (e.g., black, white, or green tea, soja, grapes, and berries). The naturally occurring phenols are referred to as flavonoids and procyanides. Several studies have shown the antioxidant activity of phenols, which is associated with their chemical structure [40]. Thring et al. [41] assessed 23 plant extracts for their antiaging properties as anti-elastase and anti-collagenase activities, and antioxidant activity along with their phenolic content. The white tea showed the highest anti-elastase and anticollagenase activities as well as the highest antioxidant activity and phenolic content. Elmets et al. [42] demonstrated in an in vivo study that the topical application of green tea extracts results in a dose-dependent inhibition of the erythema response evoked by UV radiation. Histologically, skin treated with green tea extracts reduced the number of sunburn cells and protected epidermal Langerhans cells from UV damage. Few randomized placebocontrolled clinical trials with green tea extracts (listed in Table 4) have shown improvement in elastin content on skin biopsies and improvement in skin texture [43].

Mohammad et al. [44] showed in a preliminary experiment that Prosopis cineraria bark extract has a significant amount of phenolic compounds. In an in vivo 
Table 4. Human studies on plant-based ingredients [35, 42-44, 50, 98, 99]

\begin{tabular}{|c|c|c|c|c|}
\hline Study & Study design & $n$ & Treatment $\operatorname{arm}(\mathrm{s})$ & Efficacy \\
\hline \multicolumn{5}{|c|}{ Grean tea extracts } \\
\hline $\begin{array}{l}\text { Elmets } \\
\text { et al. [42] }\end{array}$ & $\begin{array}{l}\text { Not further } \\
\text { specified }\end{array}$ & 6 & $\begin{array}{l}\text { Areas of normal skin were treated with an } \\
\text { extract of green tea; } 30 \text { min later, the treated sites } \\
\text { were exposed to 2-MED solar-simulated } \\
\text { radiation; UV-treated skin was examined } \\
\text { clinically for UV-induced erythema, } \\
\text { histologically for the presence of sunburn cell or } \\
\text { Langerhans cell distribution }\end{array}$ & $\begin{array}{l}\text { Dose-dependent inhibition of the erythema response evoked by UV radiation; } \\
\text { on histologic examination, skin treated with green tea extract reduced the } \\
\text { number of sunburn cells and protected epidermal Langerhans cells from UV } \\
\text { damage }\end{array}$ \\
\hline $\begin{array}{l}\text { Chiu } \\
\text { et al. [43] }\end{array}$ & $\mathrm{R}, \mathrm{DB}, \mathrm{PC}$ & 40 & $\begin{array}{l}\text { Combination regimen of } 10 \% \text { green tea cream } \\
\text { and } 300 \mathrm{mg} \text { green tea oral supplementation } \\
\text { twice daily vs. a placebo regimen for } 8 \text { weeks }\end{array}$ & $\begin{array}{l}\text { No significant differences were noted between groups on any of the } \\
\text { dermatologist-rated parameters; significantly greater improvement in elastin } \\
\text { content of skin biopsies in the treatment group compared with controls }(p< \\
0.05 \text { ) }\end{array}$ \\
\hline Syed [98, P25] & $\mathrm{R}, \mathrm{DB}, \mathrm{PC}$ & 60 & $\begin{array}{l}2 \% \text { epigallocatechin gallate (found in green tea) } \\
\text { in a hydrophilic gel vs. placebo gel b.i.d. for } 4 \\
\text { weeks }\end{array}$ & $\begin{array}{l}\text { Marked improvement in skin texture noted in } 46.7 \% \text { of subjects: } 83.3 \% \text { of } \\
\text { experimental group and } 10.0 \% \text { of the control group improved }\end{array}$ \\
\hline \multicolumn{5}{|c|}{$2 \%$ Prosopis cineraria bark } \\
\hline $\begin{array}{l}\text { Mohammad } \\
\text { et al. [44] }\end{array}$ & $\mathrm{R}, \mathrm{SB}, \mathrm{PC}, \mathrm{RL}$ & 9 & $\begin{array}{l}2 \% \text { Prosopis cineraria bark extract loaded } \\
\text { emulsion formulation vs. base formulation } \\
\text { applied for } 8 \text { weeks }\end{array}$ & $\begin{array}{l}\text { The formulation decreased the skin melanin, erythema, and sebum contents } \\
\text { up to } 79 \% \text {, but increased skin hydration and elasticity up to } 2 \times\end{array}$ \\
\hline \multicolumn{5}{|l|}{ Ferulic acid } \\
\hline $\begin{array}{l}\text { Murray } \\
\text { et al. [35] }\end{array}$ & $\mathrm{R}, \mathrm{PC}, \mathrm{RL}$ & 9 & $\begin{array}{l}\text { Solution of } 15 \% \text { L-ascorbic acid, } 1 \% \text { DL- } \alpha \text { - } \\
\text { tocopherol, and } 0.5 \% \text { trans ferulic acid (CEF) vs. } \\
\text { vehicle only applied daily for } 4 \text { days to separate } \\
\text { patches; on day } 4 \text { skin irradiation with solar- } \\
\text { simulated UV radiation }\end{array}$ & $\begin{array}{l}\text { CEF provided substantial protection against UV-induced erythema, apoptosis, } \\
\text { and DNA mutation vs. vehicle-treated skin }\end{array}$ \\
\hline $\begin{array}{l}\text { Salja } \\
\text { et al. [99] }\end{array}$ & PG & 6 & $\begin{array}{l}\text { Caffeic or ferulic acid solution immediately } \\
\text { applied to UV-B irradiated sites on the forearm }\end{array}$ & $\begin{array}{l}\text { Caffeic acid and ferulic acid proved a significant protection to the skin against } \\
\text { UVB-induced erythema vs. controls }\end{array}$ \\
\hline $\begin{array}{l}\text { Oresajo } \\
\text { et al. }[50]\end{array}$ & PG, PC & 10 & $\begin{array}{l}\text { Vitamin C, ferulic acid, and phloretin } \\
\text { (CFerPhlor) or vehicle alone (control) were } \\
\text { applied to back skin daily for } 4 \text { days; skin was } \\
\text { irradiated with solar-simulated UV } 1-5 \text { times } \\
\text { MED }\end{array}$ & $\begin{array}{l}\text { CferPhlor-treated site showed statistically significant reduction in } \\
\text { erythema compared to the vehicle-treated control site }\left({ }^{*} p<0.01\right) \text { at all MEDs } \\
\text { tested }\end{array}$ \\
\hline
\end{tabular}

DB, double-blind; $n$, number of participants; MED, minimal erythema dose; PC, placebo controlled; PG, parallel group; R, randomized; RL, right-left comparison; SB, single blind.

study with 9 volunteers, they measured an increase in hydration and elasticity compared to the base formulation.

Resveratrol, which is also a phenol, is another promising active ingredient. It is contained in various plants (including grapes, grapefruits, and nuts). Just like a low-calorie diet, resveratrol promotes the expression of sirtuin genes, leading to longer cell survival [45]. Resveratrol effectively prevented UVB-induced skin edema in a preclinical study [46].

Another important active ingredient of the phenol family is ferulic acid (4-hydroxy-3-methoxycinnamic acid), which is widely present in the cell walls of numerous plants, including fruits, vegetables, and grains [47, 48]. Today, it is mainly used as a photoprotective agent in skin products. Its photoprotective effect has been demonstrated in several studies $[35,49,50]$. The synergistic effect of ferulic acid with vitamins $\mathrm{C}, \mathrm{E}$, and $\beta$-carotene is another promising and interesting aspect $[35,50]$. Lin et al. [36] demonstrated that the addition of ferulic acid to a solution containing vitamins $\mathrm{C}$ and $\mathrm{E}$ doubled the skinprotective capacity of the formulation, from 4 - to 8 -fold.

\section{Ectoine}

Ectoine is an organic molecule of low molecular weight occurring in halophilic bacteria [51]. These bacteria grow under extreme conditions (dryness, high temperatures, and intensive UV irradiation) and protect themselves against these stressors by synthesizing ectoine.

Pretreatment with ectoine before sun exposure prevents the UV-induced reduction in Langerhans cells [52]. Furthermore, it was shown that ectoine protects the skin from the effects of UVA-induced cell damage in different ways; it prevents the formation of ceramide by singletoxygen-quenching properties, and it prevents mutations 
Table 5. Human studies on peptides [58-61, 68-73]

\begin{tabular}{|c|c|c|c|c|c|}
\hline Peptide & Study & Study design & $n$ & Treatment $\operatorname{arm}(\mathrm{s})$ & Efficacy \\
\hline \multicolumn{6}{|c|}{ Signal peptides: modulator of dermal extracellular matrix } \\
\hline \multirow{3}{*}{$\begin{array}{l}\text { Lysine- } \\
\text { threonine- } \\
\text { threonine- } \\
\text { lysine-serine } \\
\text { (KTTS) }\end{array}$} & $\begin{array}{l}\text { Robinson } \\
\text { et al. [58] }\end{array}$ & $\mathrm{R}, \mathrm{DB}, \mathrm{PC}, \mathrm{RL}$ & 93 & $\begin{array}{l}\text { Pal-KTTKS O/W moisturizer vs. placebo } \\
\mathrm{O} / \mathrm{W} \text { moisturizer for } 12 \text { weeks }\end{array}$ & $\begin{array}{l}\text { Significant improvement vs. placebo control for reduction } \\
\text { in wrinkles/fine lines }\end{array}$ \\
\hline & $\begin{array}{l}\text { Lintner } \\
{[59]}\end{array}$ & $\begin{array}{l}\text { Not further } \\
\text { specified }\end{array}$ & 16 & pal-KTTS vs. retinol & $\begin{array}{l}\text { Similar wrinkle reduction and increase in skin thickness in } \\
\text { both groups }\end{array}$ \\
\hline & $\mathrm{Fu}[60]$ & $\mathrm{R}, \mathrm{PG}$ & 196 & $\begin{array}{l}5 \% \text { niacinamide, pal-KTTS, antioxidant, } \\
\text { retinyl propionate vs. } 0.02 \% \text { tretinoin for } 8 \\
\text { weeks }\end{array}$ & $\begin{array}{l}\text { Significantly improved wrinkles relative to the tretinoin } \\
\text { regimen }\end{array}$ \\
\hline \multirow[t]{2}{*}{$\begin{array}{l}\text { Gly-Glu- } \\
\text { Lys-Gly } \\
\text { (GEKG) }\end{array}$} & $\begin{array}{l}\text { Farwick } \\
\text { et al. }\{61]\end{array}$ & $\mathrm{R}, \mathrm{DB}, \mathrm{PC}$ & 10 & GEGK vs. placebo cream for 8 weeks & $\begin{array}{l}\text { Histochemical analyses indicate increased formation of } \\
\text { procollagen, hyaluronic acid, and fibronectin; significant } \\
\text { improvement in skin physiological and clinical parameters } \\
\text { such as skin wrinkles and skin roughness }\end{array}$ \\
\hline & $\begin{array}{l}\text { Farwick } \\
\text { et al. [61] }\end{array}$ & $\mathrm{R}, \mathrm{DB}, \mathrm{PC}$ & 30 & GEGK vs. placebo-cream for 8 weeks & $\begin{array}{l}\text { Improvement in skin physiological and clinical parameters } \\
\text { such as skin wrinkles and skin roughness }\end{array}$ \\
\hline \multicolumn{6}{|c|}{ Carrier peptide: stimulates collagen and elastin synthesis } \\
\hline \multirow{4}{*}{$\begin{array}{l}\text { Glycil- } \\
\text { L-histidyl- } \\
\text { L-lysine } \\
\text { (GHK) }\end{array}$} & $\begin{array}{l}\text { Finkley } \\
\text { et al. [68] }\end{array}$ & $\mathrm{R}, \mathrm{DB}, \mathrm{PG}, \mathrm{PC}$ & 67 & GHK-Cu vs. placebo creams & $\begin{array}{l}\text { Significant improvement in skin laxity and clarity with } \\
\text { decreased wrinkles }\end{array}$ \\
\hline & $\begin{array}{l}\text { Leyden J } \\
\text { et al. }[69, \text { P69] }\end{array}$ & $\mathrm{R}, \mathrm{DB}, \mathrm{PC}$ & 41 & $\begin{array}{l}\text { GHK-Cu vs. placebo and vitamin } \mathrm{K} \text { cream } \\
\text { around the eyes }\end{array}$ & $\begin{array}{l}\text { Reduction in lines and wrinkles, increase in skin density and } \\
\text { thickness around the eyes }\end{array}$ \\
\hline & $\begin{array}{l}\text { Leyden } \\
\text { et al. }[69, \text { P68] }\end{array}$ & $\mathrm{R}, \mathrm{DB}, \mathrm{PC}$ & 71 & GHK-Cu vs. placebo creams & Significant improvement in skin texture after 12 weeks \\
\hline & $\begin{array}{l}\text { Abdulghani } \\
\text { and Gottlieb [73] }\end{array}$ & $\begin{array}{l}\text { Non-R, AC, } \\
\text { PG, WP }\end{array}$ & 20 & $\begin{array}{l}\text { Topical tretinoin, topical vitamin C, topical } \\
\text { GHK-Cu, topical melatonin; application on } \\
\text { thigh skin for } 12 \text { weeks }\end{array}$ & $\begin{array}{l}\text { Increase in procollagen synthesis: } 4 / 10,5 / 10,5 / 10 \text {, and } 7 / 10 \\
\text { of patients showed response to tretinoin, vitamin } \mathrm{C} \text {, } \\
\text { melatonin, and GHK-Cu, respectively }\end{array}$ \\
\hline \multicolumn{6}{|c|}{ Neurotransmitter inhibitor peptides: modulates acetylcholine transmission } \\
\hline \multirow{3}{*}{$\begin{array}{l}\text { Acetyl } \\
\text { hexa- } \\
\text { peptide- } \\
3 \text { (Ac-Glu- } \\
\text { Glu-Met- } \\
\text { Gln-Arg- } \\
\text { Arg-NH }{ }_{2} \text { ) }\end{array}$} & $\begin{array}{l}\text { Raikou } \\
\text { et al. }[71]\end{array}$ & $\mathrm{R}, \mathrm{PG}$ & 24 & $\begin{array}{l}\text { Acetyl hexapeptide- } 3 \text { with tripeptide- } 10 \\
\text { citrulline (group G1), tripeptide- } 10 \text { citrulline } \\
\text { (group, G2), acetyl hexapeptide- } 3 \text { (group G3), } \\
\text { or neither peptide (group G4) for } 60 \text { days }\end{array}$ & Significant reduction in wrinkles (up to $30 \%$ ) \\
\hline & $\begin{array}{l}\text { Blanes-Mira } \\
\text { et al. [70] }\end{array}$ & $\mathrm{PC}, \mathrm{OL}$ & 10 & $\begin{array}{l}\mathrm{O} / \mathrm{W} \text { emulsion containing } 10 \% \text { acetyl } \\
\text { hexapeptide- } 3 \text { solution vs. placebo creams for } \\
30 \text { days }\end{array}$ & $\begin{array}{l}27 \% \text { in depth of wrinkles after } 30 \text { days ( } 10 \% \text { reduction in } \\
\text { placebo group) }\end{array}$ \\
\hline & $\begin{array}{l}\text { Wang } \\
\text { et al. [72] }\end{array}$ & $\mathrm{R}, \mathrm{DB}, \mathrm{PC}, \mathrm{PG}$ & 60 & $\begin{array}{l}\text { Acetyl hexapeptide- } 3 \text { vs. placebo at a 3:1 ratio } \\
\text { twice daily for } 4 \text { weeks }\end{array}$ & Significant reduction in depth of wrinkles \\
\hline
\end{tabular}

AC, active controlled; DB, double-blind; $n$, number of participants; OL, open label; PC, placebo controlled; PG, parallel group; R, randomized; RL, right-left comparison; SB, single-blind; WP, within patient.

in the mitochondrial DNA in dermal fibroblasts [53]. In an in vivo study with 104 volunteers, Heinrich et al. [54] demonstrated that a formulation containing $2 \%$ ectoine was more effective in terms of skin hydration, skin elasticity, and skin surface structure than vehicle-only treatment.

\section{Bioactive Peptides}

Peptides are formed from short amino acid sequences and confer a diverse range of biological effects [55]. Active sequences of these peptides can be isolated and synthetically modified to further enhance their biological activities [56].
Along with health benefits demonstrated in areas such as inflammation, wound healing, angiogenesis, and antimicrobial defense, bioactive peptides are also being explored for their use in cosmeceuticals [56].

These topical peptides can be categorized into 4 groups:

- signal peptides;

- carrier peptides;

- neurotransmitter inhibitor peptides; and

- enzyme inhibitor peptides

The first 3 groups have the most data on skin rejuvenation (Table 5). The peptides with the highest evidence are explained in more detail below. 
Signal peptides increase matrix cell activities and stimulate protein production in general and collagen synthesis in specific. Substances with most existing data are the procollagen-I-derived pentamer lysine-threonine-threonine-lysine-serine (KTTS), which stimulates the production of collagens I and III and fibronectin in vitro in a time- and dose-dependent manner, and the copper tripeptide glycil-L-histidyl-L-lysine (GHK) [57]. The latter also acts as a carrier peptide.

To overcome permeability issues, palmitoyl is added to the peptide fragments.

Several clinical published studies have shown that topical formulations containing palmitoyl-KTTS have the capacity to reduce fine lines, wrinkles, and improve skin texture significantly $[58,59]$. However, most of reported clinical benefits were obtained by using a formulation containing palmitoyl-KTTKS and other active ingredients (e.g., niacinamide and vitamin E), or at least in the presence of a basic moisturizer, suggesting that the observed benefits may not be solely produced by the conjugated peptide. Furthermore, study design and data evaluation are not described in detail in all studies, except for the studies by Robinson et al. [58] and Fu et al. [60].

A more recent signal peptide is the tetrapeptide GEKG (Gly-Glu-Lys-Gly), represented as a sequence in several extracellular matrix proteins. When applied to human dermal fibroblasts in vitro, the peptide caused up-regulation of fibronectin, HA synthase, and pro-collagen I mRNA [61]. Tested topically on 10 persons in a doubleblind, randomized, placebo-controlled trial over 8 weeks, GEKG led to increased levels of collagen I mRNA and increased formation of procollagen I, HA, and fibronectin. Significant improvements in the elasticity of skin (measured by resilient distension) were claimed in further clinical studies [61].

The tripeptide-1 glycyl-L-histidyl-L-lysine (GHK) is primarily known as carrier peptide. This kind of peptide facilitates the transportation of important substances. The major application of GHK is to deliver important trace elements [62]. GHK is a fragment of the $\alpha_{2}$-chain of collagen I and exhibits a high affinity for copper (I) ions, forming spontaneously a tripeptide-copper complex $(\mathrm{GHK}-\mathrm{Cu})[63,64]$.

Originally, GHK-Cu was studied in the skin for its ability to promote wound healing $[65,66]$. It was further shown to be able to restore the function of irradiated fibroblasts. Consequently, it also has to have effects on DNA repair [67]. A few placebo-controlled clinical studies claimed $\mathrm{GHK}-\mathrm{Cu}$ improves skin quality in women $[68,69]$.
Neurotransmitter inhibitor peptides mimic the action of botulinum toxin by emulating the amino acid sequence of the synaptic protein, SNAP-25. They inhibit acetylcholine release at the neuromuscular junction and have curare-like effects [62].

Acetyl hexapeptide- 3 is one of the best-studied peptides in this group. A clinical vehicle-controlled study by Blanes-Mira et al. [70] showed that 10\% acetyl hexapeptide- 3 reduced the depth of periorbital wrinkles up to $30 \%$ (vs. 10\%) after 30 days of use. A more recent prospective, randomized, controlled study on 24 female volunteers with a mean age of 45 years found similar results [71]. Yet, these results should be interpreted with caution due to the small number of patients per group. In another randomized trial, acetyl hexapeptide- 3 or placebo was applied to periorbital wrinkles of 60 Chinese subjects twice daily for 4 weeks. In the objective evaluation, silicone replicas of the skin at the application area were made before and after the treatment, which were analyzed by a wrinkle analysis apparatus. Analysis showed a significant reduction in the depth of wrinkles in the treatment arm [72].

\section{Combinations}

Recent studies suggest that the combination of antioxidants and cell regulators may multiply the antiaging effects. Fu et al. [60] compared the combination of niacinamide/pentapeptide/retinyl propionate to a formulation with $0.02 \%$ retinoic acid in a vehicle-controlled, randomized, in vivo study with 196 patients. The combination of niacinamide/pentapeptide/retinyl propionate led to a significant reduction in wrinkles after 8 weeks, whereas similar results with the retinoic acid formulation could only be achieved after 24 weeks.

\section{Conclusion}

Cosmetic products with targeted ingredients are increasingly used to prevent skin aging and to maintain results after skin rejuvenation procedures. Meanwhile, there is a large number of products, marketed as cosmeceuticals, which claim that their ingredients actively improve skin health and have rejuvenation capabilities. However, most products available on the market lack evidence of clinical benefits from use of sufficiently high concentrations of these ingredients. Additionally, clinical trial data for their clinical efficacy are meagre due to various factors including permeability with regard to the skin barrier and stability upon light exposure.
10

Dermatology

DOI: $10.1159 / 000509296$
Imhof/Leuthard 
The best evidence (level A, randomized, double-blind, placebo-controlled studies) for the effectiveness of active substances in local therapeutics so far is available for vitamins $\mathrm{B}_{3}, \mathrm{C}$, and $\mathrm{A}$, and their derivatives; as well as for various $\alpha$-hydroxy acids such as glycolic or $\alpha$-lipoic acid. Furthermore, some peptides are relatively well investigated. Several scientific studies indicate that palmitoyl-KTTS has a capacity to significantly reduce signs of skin aging on the face [58-60]. In vivo synergistic activity of cell regulators and antioxidants, as observed in some studies [60, 73], makes the combination of differently acting active substances promising for cosmetic and dermatological applications.

A major shortcoming in published studies is that most industry-driven studies do not meet the standards required for a scientific publication yet. Placebo-controlled, double-blind studies, the standard in medical research, are still too rare for cosmetic products. Most of the existing scientific investigations were carried out on very small number of subjects, mainly female volunteers, with a wide age range. Good clinical practice was often lacking in the protocols.

The product manufacturers and universities ought to work together in this field and generate more data on safety and efficacy, with the aim of improving the benefit for patients.

Qualitatively, evidenced studies would also justify high market prices for well-studied cosmetic products.

\section{Key Message}

Scientific evidence is still scarce for many topical antiaging products.

\section{Acknowledgment}

The authors thank Gregor Schäfer, MD, and Ghugtyal Vikram, $\mathrm{PhD}$, for their valuable comments on this manuscript.

\section{Statement of Ethics}

This research did not involve human participants or animals as this was a review of existing publications, and no primary data were collected. Written informed consent was, therefore, not obtained, and ethical approval was not sought.

\section{Conflict of Interest Statement}

The authors have no conflicts of interest to declare.

\section{Author Contributions}

L.I. and D.L. take responsibility for the integrity of the data and the accuracy of the data analysis. L.I. designed the study and critically revised the manuscript for important intellectual content.

\section{References}

1 Makrantonaki E, Vogel M, Scharffetter-Kochanek K, Zouboulis CC. [Skin aging: molecular understanding of extrinsic and intrinsic processes]. Hautarzt. 2015 Oct;66(10):730-7.

2 Ganceviciene R, Liakou AI, Theodoridis A, Makrantonaki E, Zouboulis CC. Skin anti-aging strategies. Dermatoendocrinol. 2012 Jul; 4(3):308-19.

3 Shin JW, Kwon SH, Choi JY, Na JI, Huh CH, Choi HR, et al. Molecular Mechanisms of Dermal Aging and Antiaging Approaches. Int J Mol Sci. 2019 Apr;20(9):E2126.

4 Rinnerthaler M, Bischof J, Streubel MK, Trost A, Richter K. Oxidative stress in aging human skin. Biomolecules. 2015 Apr;5(2):545-89.

5 Commander SJ, Chang D, Fakhro A, Nigro MG, Lee EI. Noninvasive Facial Rejuvenation. Part 1: Patient-Directed. Semin Plast Surg. 2016 Aug;30(3):129-33.

6 Hubbard BA, Unger JG, Rohrich RJ. Reversal of skin aging with topical retinoids. Plast Reconstr Surg. 2014 Apr;133(4):481e-90e.

7 Kligman AM, Grove GL, Hirose R, Leyden JJ. Topical tretinoin for photoaged skin. J Am Acad Dermatol. 1986 Oct;15(4 Pt 2):836-59.
8 Griffiths CE, Russman AN, Majmudar G, Singer RS, Hamilton TA, Voorhees JJ. Restoration of collagen formation in photodamaged human skin by tretinoin (retinoic acid). N Engl J Med. 1993 Aug;329(8):530-5.

9 Kang S. Photoaging and tretinoin. Dermatol Clin. 1998 Apr;16(2):357-64.

10 Creidi P, Vienne MP, Ochonisky S, Lauze C, Turlier V, Lagarde JM, et al. Profilometric evaluation of photodamage after topical retinaldehyde and retinoic acid treatment. J Am Acad Dermatol. 1998 Dec;39(6):960-5.

11 Chiu A, Kimball AB. Topical vitamins, minerals and botanical ingredients as modulators of environmental and chronological skin damage. Br J Dermatol. 2003 Oct;149(4):681-91.

12 Mukherjee S, Date A, Patravale V, Korting HC, Roeder A, Weindl G. Retinoids in the treatment of skin aging: an overview of clinical efficacy and safety. Clin Interv Aging. 2006;1(4):327-48.

13 Ramos-e-Silva M, Celem LR, Ramos-e-Silva S, Fucci-da-Costa AP. Anti-aging cosmetics: facts and controversies. Clin Dermatol. 2013 Nov-Dec;31(6):750-8.
14 Van Scott EJ, Yu RJ. Hyperkeratinization, corneocyte cohesion, and alpha hydroxy acids. J Am Acad Dermatol. 1984 Nov;11(5 Pt 1):867-79.

15 Proksch E, Lachapelle JM. The management of dry skin with topical emollients-recent perspectives. J Dtsch Dermatol Ges. 2005 Oct; 3(10):768-74.

$16 \mathrm{Kim}$ SJ, Won YH. The effect of glycolic acid on cultured human skin fibroblasts: cell proliferative effect and increased collagen synthesis. J Dermatol. 1998 Feb;25(2):85-9.

17 Newman N, Newman A, Moy LS, Babapour R, Harris AG, Moy RL. Clinical improvement of photoaged skin with $50 \%$ glycolic acid. A double-blind vehicle-controlled study. Dermatol Surg. 1996 May;22(5):455-60.

18 Ditre CM, Griffin TD, Murphy GF, Sueki H, Telegan B, Johnson WC, et al. Effects of alphahydroxy acids on photoaged skin: a pilot clinical, histologic, and ultrastructural study. J Am Acad Dermatol. 1996 Feb;34(2 Pt 1):187-95.

19 Smith WP. Epidermal and dermal effects of topical lactic acid. J Am Acad Dermatol. 1996 Sep;35(3 Pt 1):388-91. 
20 Bukhari SNA, Roswandi NL, Waqas M, Habib H, Hussain F, Khan S, et al. Hyaluronic acid, a promising skin rejuvenating biomedicine: A review of recent updates and pre-clinical and clinical investigations on cosmetic and nutricosmetic effects. Int J Biol Macromol. 2018 Dec; 120(Pt B):1682-95.

21 Kaya G TC, Sorg O, Hotz R, Grand D, Carraux P, Didierjean L, Stamenkovic I, SauraT JH. Hyaluronate fragments reverse skin atrophy by a CD44-dependent mechanism. PLoS Med. 2006 Dec;3(12):e493.

22 Pavicic T, Gauglitz GG, Lersch P, Schwach-Abdellaoui K, Malle B, Korting HC, et al. Efficacy of cream-based novel formulations of hyaluronic acid of different molecular weights in anti-wrinkle treatment. J Drugs Dermatol. 2011 Sep;10(9):990-1000.

23 Surjana D, Halliday GM, Damian DL. Nicotinamide enhances repair of ultraviolet radiationinduced DNA damage in human keratinocytes and ex vivo skin. Carcinogenesis. 2013 May; 34(5):1144-9.

24 Kawada A, Konishi N, Oiso N, Kawara S, Date A. Evaluation of anti-wrinkle effects of a novel cosmetic containing niacinamide. J Dermatol. 2008 Oct;35(10):637-42.

25 Bissett DL, Oblong JE, Berge CA. Niacinamide: A B vitamin that improves aging facial skin appearance. Dermatol Surg. 2005 Jul;31(7 Pt 2): 860-5.

26 Bissett DL, Miyamoto K, Sun P, Li J, Berge CA. Topical niacinamide reduces yellowing, wrinkling, red blotchiness, and hyperpigmented spots in aging facial skin. Int J Cosmet Sci. 2004 Oct;26(5):231-8.

27 Ronchetti IP, Quaglino D Jr, Bergamini G. Ascorbic acid and connective tissue. Subcell Biochem. 1996;25:249-64.

28 Wenstrup RJ, Murad S, Pinnell SR. EhlersDanlos syndrome type VI: clinical manifestations of collagen lysyl hydroxylase deficiency. J Pediatr. 1989 Sep;115(3):405-9.

29 Nusgens BV, Humbert P, Rougier A, Colige AC, Haftek M, Lambert CA, et al. Topically applied vitamin $\mathrm{C}$ enhances the mRNA level of collagens I and III, their processing enzymes and tissue inhibitor of matrix metalloproteinase 1 in the human dermis. J Invest Dermatol. 2001 Jun;116(6):853-9.

30 Raschke T, Koop U, Düsing HJ, Filbry A, Sauermann K, Jaspers S, et al. Topical activity of ascorbic acid: from in vitro optimization to in vivo efficacy. Skin Pharmacol Physiol. 2004 JulAug;17(4):200-6.

31 Fitzpatrick RE, Rostan EF. Double-blind, halfface study comparing topical vitamin $\mathrm{C}$ and vehicle for rejuvenation of photodamage. Dermatol Surg. 2002 Mar;28(3):231-6.

32 Haftek M, Mac-Mary S, Le Bitoux MA, Creid $\mathrm{P}$, Seité S, Rougier A, et al. Clinical, biometric and structural evaluation of the long-term effects of a topical treatment with ascorbic acid and madecassoside in photoaged human skin. Exp Dermatol. 2008 Nov;17(11):946-52.

33 Humbert PG, Haftek M, Creidi P, Lapière C, Nusgens B, Richard A, et al. Topical ascorbic acid on photoaged skin. Clinical, topographical and ultrastructural evaluation: double-blind study vs. placebo. Exp Dermatol. 2003 Jun; 12(3):237-44.

34 Ricciarelli R, Maroni P, Ozer N, Zingg JM, Azzi A. Age-dependent increase of collagenase expression can be reduced by alpha-tocopherol via protein kinase $\mathrm{C}$ inhibition. Free Radic Biol Med. 1999 Oct;27(7-8):729-37.

35 Murray JC, Burch JA, Streilein RD, Iannacchione MA, Hall RP, Pinnell SR. A topical antioxidant solution containing vitamins $\mathrm{C}$ and $\mathrm{E}$ stabilized by ferulic acid provides protection for human skin against damage caused by ultraviolet irradiation. J Am Acad Dermatol. 2008 Sep; 59(3):418-25.

36 Lin FH, Lin JY, Gupta RD, Tournas JA, Burch JA, Selim MA, et al. Ferulic acid stabilizes a solution of vitamins $\mathrm{C}$ and $\mathrm{E}$ and doubles its photoprotection of skin. J Invest Dermatol. 2005 Oct;125(4):826-32.

37 Bissett DL, Chatterjee R, Hannon DP. Photoprotective effect of superoxide-scavenging antioxidants against ultraviolet radiation-induced chronic skin damage in the hairless mouse. Photodermatol Photoimmunol Photomed. 1990 Apr;7(2):56-62.

38 Bhagavan HN, Chopra RK. Coenzyme Q10: absorption, tissue uptake, metabolism and pharmacokinetics. Free Radic Res. 2006 May; 40(5):445-53

39 Inui M, Ooe M, Fujii K, Matsunaka H, Yoshida M, Ichihashi M. Mechanisms of inhibitory effects of CoQ10 on UVB-induced wrinkle formation in vitro and in vivo. Biofactors. 2008; 32(1-4):237-43.

40 Leopoldini M, Russo N, Toscano M. The molecular basis of working mechanism of natural polyphenolic antioxidants. Food Chem. 2011; 125(2):288-306.

41 Thring TS, Hili P, Naughton DP. Anti-collagenase, anti-elastase and anti-oxidant activities of extracts from 21 plants. BMC Complement Altern Med. 2009 Aug;9(1):27.

42 Elmets CA, Singh D, Tubesing K, Matsui M, Katiyar S, Mukhtar H. Cutaneous photoprotection from ultraviolet injury by green tea polyphenols. J Am Acad Dermatol. 2001 Mar;44(3): $425-32$.

43 Chiu AE, Chan JL, Kern DG, Kohler S, Rehmus WE, Kimball AB. Double-blinded, placebocontrolled trial of green tea extracts in the clinical and histologic appearance of photoaging skin. Dermatol Surg. 2005 Jul;31(7 Pt 2):855-60.

44 Mohammad IS, Naveed M, Ijaz S, Shumzaid M Hassan S, Muhammad KS, et al. Phytocosmeceutical formulation development, characterization and its in-vivo investigations. Biomed Pharmacother. 2018 Nov; 107:806-17.

45 Singh UP, Singh NP, Singh B, Hofseth LJ, Price RL, Nagarkatti M, et al. Resveratrol (trans3,5,4'-trihydroxystilbene) induces silent mating type information regulation-1 and downregulates nuclear transcription factor-kappaB activation to abrogate dextran sulfate sodiuminduced colitis. J Pharmacol Exp Ther. 2010 Mar;332(3):829-39.
46 Baxter RA. Anti-aging properties of resveratrol review and report of a potent new antioxidant skin care formulation. J Cosmet Dermatol. 2008 Mar;7(1):2-7.

47 Bourne LC, Rice-Evans C. Bioavailability of ferulic acid. Biochem Biophys Res Commun. 1998 Dec;253(2):222-7.

48 Svobodová A, Psotová J, Walterová D. Natural phenolics in the prevention of UV-induced skin damage. A review. Biomed Pap Med Fac Univ Palacky Olomouc Czech Repub. 2003 Dec;147(2):137-45.

49 Saija A, Tomaino A, Trombetta D, De Pasquale A, Uccella N, Barbuzzi T, et al. In vitro and in vivo evaluation of caffeic and ferulic acids as topical photoprotective agents. Int J Pharm. 2000 Apr;199(1):39-47.

50 Oresajo C, Stephens T, Hino PD, Law RM, Yatskayer M, Foltis $\mathrm{P}$, et al. Protective effects of a topical antioxidant mixture containing vitamin C, ferulic acid, and phloretin against ultraviolet-induced photodamage in human skin. J Cosmet Dermatol. 2008 Dec;7(4):290-7.

51 Galinski EA. Compatible solutes of halophilic eubacteria: molecular principles, water-solute interaction, stress protection. Experientia. 1993;49(6-7):487-96.

52 Pfluecker FB, Hitzel S, Witte G, Beck J, Lergenmueller M, Driller H. Complete photoprotection - going beyond visible endpoints. SÖFW. 2005; 131:20-30.

53 Berneburg M, Grether-Beck S, Kürten V, Ruzicka T, Briviba K, Sies H, et al. Singlet oxygen mediates the UVA-induced generation of the photoaging-associated mitochondrial common deletion. J Biol Chem. 1999 May;274(22): 15345-9.

54 Heinrich U, Garbe B, Tronnier H. In vivo assessment of Ectoin: a randomized, vehicle-controlled clinical trial. Skin Pharmacol Physiol. 2007;20(4):211-8

55 Pai VV, Bhandari P, Shukla P. Topical peptides as cosmeceuticals. Indian J Dermatol Venereol Leprol. 2017 Jan-Feb;83(1):9-18.

56 Reddy BY, Jow T, Hantash BM. Bioactive oligopeptides in dermatology: part II. Exp Dermatol. 2012 Aug;21(8):569-75.

57 Katayama K, Armendariz-Borunda J, Raghow R, Kang AH, Seyer JM. A pentapeptide from type I procollagen promotes extracellular matrix production. J Biol Chem. 1993 May; 268(14):9941-4.

58 Robinson LR, Fitzgerald NC, Doughty DG, Dawes NC, Berge CA, Bissett DL. Topical palmitoyl pentapeptide provides improvement in photoaged human facial skin. Int J Cosmet Sci. 2005 Jun;27(3):155-60.

59 Lintner K. Promoting production in the extracellular matrix without compromising barrier. Cutis. 2002 Dec;70(6 Suppl):13-6.

60 Fu JJ, Hillebrand GG, Raleigh P, Li J, Marmor MJ, Bertucci V, et al. A randomized, controlled comparative study of the wrinkle reduction benefits of a cosmetic niacinamide/peptide/ retinyl propionate product regimen vs. a prescription $0.02 \%$ tretinoin product regimen. $\mathrm{Br} J$ Dermatol. 2010 Mar;162(3):647-54. 
61 Farwick M, Grether-Beck S, Marini A, Maczkiewitz U, Lange J, Köhler T, et al. Bioactive tetrapeptide GEKG boosts extracellular matrix formation: in vitro and in vivo molecular and clinical proof. Exp Dermatol. 2011 Jul;20(7): $602-4$.

62 Gorouhi F, Maibach HI. Role of topical peptides in preventing or treating aged skin. Int $\mathrm{J}$ Cosmet Sci. 2009 Oct;31(5):327-45.

63 Zhang L, Falla TJ. Cosmeceuticals and peptides. Clin Dermatol. 2009 Sep-Oct;27(5):485-94.

64 Husein El Hadmed H, Castillo RF. Cosmeceuticals: peptides, proteins, and growth factors. J Cosmet Dermatol. 2016 Dec;15(4):514-9.

65 Maquart FX, Bellon G, Chaqour B, Wegrowski J, Patt LM, Trachy RE, et al. In vivo stimulation of connective tissue accumulation by the tripeptide-copper complex glycyl-L-histidyl-Llysine-Cu2+ in rat experimental wounds. J Clin Invest. 1993 Nov;92(5):2368-76.

66 Maquart FX, Pickart L, Laurent M, Gillery P, Monboisse JC, Borel JP. Stimulation of collagen synthesis in fibroblast cultures by the tripeptide-copper complex glycyl-L-histidyl-Llysine-Cu2+. FEBS Lett. 1988 Oct;238(2): 343-6.

67 Pollard JD, Quan S, Kang T, Koch RJ. Effects of copper tripeptide on the growth and expression of growth factors by normal and irradiated fibroblasts. Arch Facial Plast Surg. 2005 Jan-Feb; $7(1): 27-31$.

68 Finkley MB, Bhandarkar S. Copper peptide and skin. 2nd ed. In: Eisner P MH, editors. Cosmeceuticals and active cosmetics: drugs vs. cosmetics. New York: Marcel Dekker; 2005.

69 Leyden J ST, Finkley MB, Barkovic S. Skin Care Benefits of Copper Peptide Containing Eye Creams. Amer Academy Dermat Meeting, February 2002. Abstracts P68, P69.

70 Blanes-Mira C, Clemente J, Jodas G, Gil A, Fernández-Ballester G, Ponsati B, et al. A synthetic hexapeptide (Argireline) with antiwrinkle activity. Int J Cosmet Sci. 2002 Oct;24(5): 303-10.

71 Raikou V, Varvaresou A, Panderi I, Papageorgiou $\mathrm{E}$. The efficacy study of the combination of tripeptide-10-citrulline and acetyl hexapeptide-3. A prospective, randomized controlled study. J Cosmet Dermatol. 2017 Jun;16(2): 271-8.

72 Wang Y, Wang M, Xiao S, Pan P, Li P, Huo J. The anti-wrinkle efficacy of argireline, a synthetic hexapeptide, in Chinese subjects: a randomized, placebo-controlled study. Am J Clin Dermatol. 2013 Apr;14(2):147-53.

73 Abdulghani AA, Gottlieb A. Effects of topical creams containing vitamin $C$, a copper-binding peptide cream and melatonin compared with tretinoin on the ultrastructure of normal skinA pilot clinical, histologic, and ultrastructural study. Disease Management and Clinical Outcomes. 1998;1(4):136-41.

74 Piérard-Franchimont C, Castelli D, Cromphaut IV, Bertin C, Ries G, Cauwenbergh G, et al. Tensile properties and contours of aging facial skin. A controlled double-blind comparative study of the effects of retinol, melibiose-lactose and their association. Skin Res Technol. 1998 Nov;4(4):237-43.

75 Varani J, Warner RL, Gharaee-Kermani M, Phan SH, Kang S, Chung JH, et al. Vitamin A antagonizes decreased cell growth and elevated collagen-degrading matrix metalloproteinases and stimulates collagen accumulation in naturally aged human skin. J Invest Dermatol. 2000 Mar;114(3):480-6.

76 Kafi R, Kwak HS, Schumacher WE, Cho S, Hanft VN, Hamilton TA, et al. Improvement of naturally aged skin with vitamin A (retinol). Arch Dermatol. 2007 May;143(5):606-12.

77 Kang S, Duell EA, Fisher GJ, Datta SC, Wang ZQ, Reddy AP, et al. Application of retinol to human skin in vivo induces epidermal hyperplasia and cellular retinoid binding proteins characteristic of retinoic acid but without measurable retinoic acid levels or irritation. J Invest Dermatol. 1995 Oct;105(4):549-56.

78 Randhawa M, Rossetti D, Leyden JJ, Fantasia J, Zeichner J, Cula GO, et al. One-year topical stabilized retinol treatment improves photodamaged skin in a double-blind, vehicle-controlled trial. J Drugs Dermatol. 2015 Mar;14(3):27180.

79 Saurat JH, Didierjean L, Masgrau E, Piletta PA, Jaconi S, Chatellard-Gruaz D, et al. Topical retinaldehyde on human skin: biologic effects and tolerance. J Invest Dermatol. 1994 Dec;103(6): $770-4$.

80 Maddin S, Lauharanta J, Agache P, Burrows L, Zultak M, Bulger L. Isotretinoin improves the appearance of photodamaged skin: results of a 36-week, multicenter, double-blind, placebocontrolled trial. J Am Acad Dermatol. 2000 Jan; 42(1 Pt 1):56-63.

81 Weinstein GD, Nigra TP, Pochi PE, Savin RC, Allan A, Benik K, et al. Topical tretinoin for treatment of photodamaged skin. A multicenter study. Arch Dermatol. 1991 May;127(5): 659-65.

82 Olsen EA, Katz HI, Levine N, Nigra TP, Pochi $\mathrm{PE}$, Savin RC, et al. Tretinoin emollient cream for photodamaged skin: results of 48-week, multicenter, double-blind studies. J Am Acad Dermatol. 1997 Aug;37(2 Pt 1):217-26.

83 Leyden JJ, Grove GL, Grove MJ, Thorne EG, Lufrano L. Treatment of photodamaged facial skin with topical tretinoin. J Am Acad Dermatol. 1989 Sep;21(3 Pt 2):638-44.

84 Olsen EA, Katz HI, Levine N, Shupack J, Billys MM, Prawer S, et al. Tretinoin emollient cream: a new therapy for photodamaged skin. J Am Acad Dermatol. 1992 Feb;26(2 Pt 1):215-24.

85 Sendagorta E, Lesiewicz J, Armstrong RB. Topical isotretinoin for photodamaged skin. J Am Acad Dermatol. 1992 Dec;27(6 Pt 2):S15-8.

86 Ellis CN, Weiss JS, Hamilton TA, Headington JT, Zelickson AS, Voorhees JJ. Sustained improvement with prolonged topical tretinoin (retinoic acid) for photoaged skin. J Am Acad Dermatol. 1990 Oct;23(4 Pt 1):629-37.

87 Kang S, Bergfeld W, Gottlieb AB, Hickman J, Humeniuk J, Kempers S, et al. Long-term effi- cacy and safety of tretinoin emollient cream $0.05 \%$ in the treatment of photodamaged facial skin: a two-year, randomized, placebo-controlled trial. Am J Clin Dermatol. 2005;6(4): 245-53.

88 Thibault PK, Wlodarczyk J, Wenck A. A double-blind randomized clinical trial on the effectiveness of a daily glycolic acid 5\% formulation in the treatment of photoaging. Dermatol Surg. 1998 May;24(5):573-7.

89 Stiller MJ, Bartolone J, Stern R, Smith S, Kollias N, Gillies R, et al. Topical 8\% glycolic acid and $8 \%$ L-lactic acid creams for the treatment of photodamaged skin. A double-blind vehiclecontrolled clinical trial. Arch Dermatol. 1996 Jun;132(6):631-6.

90 Jacobs SW, Culbertson EJ. Effects of Topical Mandelic Acid Treatment on Facial Skin Viscoelasticity. Facial Plast Surg. 2018 Dec;34(6): 651-6.

91 El-Komy M, Shalaby S, Hegazy R, Abdel Hay R, Sherif S, Bendas E. Assessment of cubosomal alpha lipoic acid gel efficacy for the aging face: a single-blinded, placebo-controlled, right-left comparative clinical study. J Cosmet Dermatol. 2017 Sep;16(3):358-63.

92 Beitner H. Randomized, placebo-controlled, double blind study on the clinical efficacy of a cream containing $5 \% \alpha$-lipoic acid related to photoageing of facial skin. Br J Dermatol. 2003 Oct;149(4):841-9.

93 Perricone NV. Topical 5\% alpha lipoic acid cream in the treatment of cutaneous rhytids. Aesthet Surg J. 2000 May;2(3):218-22.

94 Sherif S, Bendas ER, Badawy S. The clinical efficacy of cosmeceutical application of liquid crystalline nanostructured dispersions of alpha lipoic acid as anti-wrinkle. Eur J Pharm Biopharm. 2014 Feb;86(2):251-9.

95 Pavicic T, Gauglitz GG, Lersch P, Schwach-Abdellaoui K, Malle B, Korting HC, et al. Efficacy of cream-based novel formulations of hyaluronic acid of different molecular weights in anti-wrinkle treatment. J Drugs Dermatol. 2011 Sep;10(9):990-1000.

96 Jegasothy SM, Zabolotniaia V, Bielfeldt S. Efficacy of a new topical nano-hyaluronic acid in humans. J Clin Aesthet Dermatol. 2014 Mar; 7(3):27-9.

97 Poetschke J, Schwaiger H, Steckmeier S, Ruzicka T, Gauglitz GG. [Anti-wrinkle creams with hyaluronic acid: how effective are they?]. MMW Fortschr Med. 2016 May;158(S4 Suppl 4):1-6.

98 Syed TA, Wong WH, Ahmad SA, Aly R. Phase II, clinical evaluation of $2 \%$ polyphenone (green tea extract) in a hydrophilic gel to assess improvement in damaged and premature aged facial skin. a placebo-controlled, double-blind study. JAAD. 2004 Mar;50(3 Supplement):P25.

99 Saija A, Tomaino A, Trombetta D, De Pasquale A, Uccella N, Barbuzzi T, et al. In vitro and in vivo evaluation of caffeic and ferulic acids as topical photoprotective agents. Int J Pharm. 2000 Apr 10;199(1):39-47. 